\title{
SUBSTITUTION OF CORN USING CASSAPRO (CASSAVA PROTEIN) IN FEED ON PERFORMANCES OF KAMPUNG CHICKEN
}

\author{
Bram Bintang Benara, I Sembiring, E Mirwandhono, Hamdan, and TH Wahyuni \\ Animal Production Study Program, Faculty of Agriculture, University \\ of Sumatera Utara, Jl. Prof. A. Sofyan No. 3 Kampus USU Medan \\ 20155 \\ E-mail : jpi@usu.ac.id
}

\begin{abstract}
This research was conducted at The Animal Biology Laboratory, Faculty of Agriculture, SumateraUtara University from December 2015 to March 2016. This research aimed to determine the ability of cassapro to substitute corn in feed on the performances of kampung chicken. Experimental design used in this research was completely randomized design (CRD) with 5 treatments and 4 replications. Each treatment consisted of comparison between corn and cassapro at ratio 60:0 (P0), 50:10 (P1), 40:20 (P2), 30:30 (P3), 20:40 (P4). 100 kampung chickens was used in this research with replications consists of 5 DOC.

The results showed that the average of feed consumption ( $\mathrm{g} / \mathrm{head} / \mathrm{week}$ ) on treatment $\mathrm{P} 0, \mathrm{P} 1$, P2, P3 and P4 respectively 327,9; 327,3; 326,93; 325,77 and 326,33. The average of body weight gain (g/head/week) on treatment P0, P1, P2, P3 and P4 respectively 56,46; 59,47; 60,79; 56,44 and 56,74 also the FCR on treatment P0, P1, P2, P3 and P4 respectively 5,82; 5,52; 5,38; 5,79 and 5,7. The anova result showed that there is no difference from treatments on tested parameters. The conclution of this research is that cassapro have the ability to substitute corn in kampung chicken's feed.

Keywords: Cassapro, corn, kampung chicken, performance, substitution
\end{abstract}

\section{Introduction}

Generally, the use of maize as the main ingredient in the composition of feed on poultry, causing the potential of other ingredients raw material decline. This is still a problem for farmers, especially in Indonesia, due to the high price of corn. Corn is a feed ingredient that is still imported from other cornproducing countries due to the need for corn in Indonesia is still not met by local farmers, so the price of maize becomes relatively high. On the other hand, the use of corn is also still not maximized in terms of quality because the storage of corn is not durable, so it can cause food to be quickly damaged as a result of Aflatoxin contained in corn.

Cassava has the potential as raw material for the composition of feed, because the price is relatively cheaper. Cassava also has other advantages such as easy to obtain, available many, and high content of the stones so it can be used as a carbohydrate dissolved. However, the nutrient content of cassava is still relatively low in which the protein content is only about $2-3 \%$ of the protein content of cassava is still far compared to the maize protein content of $8-8.5 \%$, so that required a processing that 
can increase nutritional content of cassava. Increasing the protein content in cassava can make cassava as animal feed with good quality.

Fermentation of solid substrates with Aspergillus Niger can be used to increase the nutrient content of cassava. Cassava that has been fermented by Aspergillus Niger as known as cassava protein (cassapro). Cassapro has a higher protein content than its original ingredients ie cassava. Thus, cassapro can be used as animal feed ingredients, especially poultry. The addition of cassapro also provides an advantage because when added to the main livestock feed can increase the digestibility of livestock against the feed. This is due to the ability of Aspergillus Niger to produce digestive enzymes such as cellulase, amylase, protease, fitase, and mananase which can help digest animal feed.

Therefore, the use of Cassapro (cassava protein) or cassava that has been fermented to increase its protein has the potential to substitute corn in poultry rations. In addition to the high metabolic energy content of $3,846.76 \mathrm{kcal} / \mathrm{g}$, where the energy content of metabolis beat the corn metabolic energy of $3,300 \mathrm{kcal} / \mathrm{g}$, so as to meet the nutritional needs of chicken.

\section{Materials and Method}

The design used was complete randomized design (RAL) with 5 treatments and 4 replications. The treatment used a maize ratio with cassapro between 60: 0 (P0), 50:10 (P1), 40:20 (P2), 30:30 (P3), 20:40 (P4). This study used 100 chickens. The variables observed were ration consumption, body weight gain and ration conversion.

\section{Results and Discussion}

\subsection{Consumption of Rations}

Ration consumption is the number of rations eaten by livestock will be used to provide basic living and for livestock production. Ration consumption can be calculated by reducing the amount of ration given with feed on the feed. Feed consumption is an important thing, because it is related to the fulfillment of needs for both basic life and production. Increased rations consumed will provide an opportunity for the body to retain more nutrients, more protein intake, so protein needs are met. Average consumption of rations during the study can be seen in Table 1 as follows:

Table 1 . Average ration consumption during the study (g/head/week)

\begin{tabular}{|c|c|c|c|c|c|c|c|}
\hline \multirow[b]{2}{*}{ Treatments } & \multicolumn{3}{|c|}{ Replication } & \multirow[b]{2}{*}{4} & \multirow[b]{2}{*}{ Total } & \multirow[b]{2}{*}{ Means } & \multirow[b]{2}{*}{$\begin{array}{c}\text { Standart } \\
\text { Deviasi }\end{array}$} \\
\hline & 1 & 2 & 3 & & & & \\
\hline P0 & 327,22 & 327,82 & 328,20 & 328,40 & 1311,64 & 327,91 & $\pm 0,52$ \\
\hline $\mathrm{P} 1$ & 328,18 & 326,60 & 327,64 & 327,02 & 1309,44 & 327,36 & $\pm 0,69$ \\
\hline $\mathrm{P} 2$ & 325,80 & 325,96 & 327,84 & 328,13 & 1307,73 & 326,93 & $\pm 1,23$ \\
\hline P3 & 325,16 & 326,18 & 327,33 & 324,40 & 1303,07 & 325,77 & $\pm 1,27$ \\
\hline $\mathrm{P} 4$ & 325,02 & 327,53 & 325,29 & 327,47 & 1305,31 & 326,33 & $\pm 1,36$ \\
\hline
\end{tabular}

Table 2. Annova ration consumption during the study $(\mathrm{g} / \mathrm{head} /$ week)

\begin{tabular}{lllllll}
\hline & & & \multicolumn{3}{c}{ FTabel } \\
\cline { 5 - 7 } SK & $\mathrm{dB}$ & $\mathrm{JK}$ & $\mathrm{KT}$ & Fhit & 0,05 & 0,01 \\
\hline Perlakuan & 4 & 400647,60 & 100161,9 & 0,938 & 3,24 & 5,29 \\
Galat & 15 & 1602583,28 & 106838,9 & & & \\
Total & 19 & 2003230,88 & & & & \\
\hline
\end{tabular}

From Table 2, it can be seen that the average consumption of chicken ration during the study was not significantly different between treatments (P0, P1, P2, P3, P4). The highest ration consumption was in $\mathrm{P} 0$ of $327.91 \mathrm{~g} /$ head / week, while the lowest ration consumption was found at P3 of 325,77. 
Based on the analysis of variance also showed results that did not differ significantly $(\mathrm{P}<0.05)$ on consumption. This shows that giving maize and cassapro did not have a significant effect on consumption. However, the consumption trend at P0 is higher when compared with P1, P2, P3 and P4. In this case it shows that maize and cassapro have the same quality and palatability.

Table 2 shows that P1, P2, P3 and P4 are lower than P0 which does not contain cassapro. Consumption statistics on $\mathrm{P} 1, \mathrm{P} 2, \mathrm{P} 3$ and $\mathrm{P} 4$ are affected by an isonutrient ration. However, after the analysis of the variance obtained that $\mathrm{F}$ count is smaller than $\mathrm{F}$ table stating that the level of consumption is not significantly different. Furthermore Tillman et al., [1] states that livestock in consuming rations is none other than to meet basic needs of life, growth, production and reproduction. Ration consumption is influenced by the environment, the balance of food substances, the quality of rations, the livestock, the growth rate, the body weight, the production rate and the palatability of the ration

\subsection{Addition of Body Weight (PBB)}

Weight gain (PBB) involves growth in the form of heavy tissue builders such as bone, heart, brain, and all other body tissues (except fat tissue) and body muscles. The weight gain can be measured by subtracting the final body weight by the initial weight of unity of time in units of grams / head / week. Weighing is done once a week. The average of chicken body weight gain obtained during the study was as Table 3 below:

Table 3. Average weight gain during the study (g/head/week)

\begin{tabular}{|c|c|c|c|c|c|c|c|}
\hline \multirow[b]{2}{*}{ Treatments } & \multicolumn{3}{|c|}{ Replication } & \multirow[b]{2}{*}{4} & \multirow[b]{2}{*}{ Total } & \multirow[b]{2}{*}{ Means } & \multirow[b]{2}{*}{$\begin{array}{l}\text { Standart } \\
\text { Deviasi }\end{array}$} \\
\hline & 1 & 2 & 3 & & & & \\
\hline P0 & 60,50 & 52,23 & 55,56 & 57,56 & 225,84 & 56,46 & 3,48 \\
\hline $\mathrm{P} 1$ & 63,88 & 58,32 & 56,11 & 59,57 & 237,88 & 59,47 & 3,27 \\
\hline $\mathrm{P} 2$ & 59,00 & 60,32 & 59,80 & 64,04 & 243,15 & 60,79 & 2,23 \\
\hline P3 & 56,75 & 59,86 & 51,61 & 57,52 & 225,74 & 56,44 & 3,48 \\
\hline $\mathrm{P} 4$ & 57,43 & 51,54 & 58,44 & 59,53 & 226,94 & 56,74 & 3,57 \\
\hline
\end{tabular}

Table 4. Annova weight gain during the study (g/head/week)

\begin{tabular}{lllllll} 
& & & \multicolumn{3}{c}{ FTabel } \\
\cline { 5 - 7 } SK & $\mathrm{dB}$ & $\mathrm{JK}$ & KT & Fhit & 0,05 & 0,01 \\
\hline Perlakuan & 4 & 12661,33 & 3165,33 & 0,939 & 3,24 & 5,29 \\
Galat & 15 & 50589,53 & 3372,64 & & & \\
Total & 19 & 63250,86 & 6537,97 & & & \\
\hline
\end{tabular}

Table 4 shows that the average of chicken body weight gain during the study was not significantly different between treatments (P0, P1, P2, P3 and P4). The highest weight gain was found in $\mathrm{P} 1$ of 87.04 gram / head / week while the lowest weight gain was found at P3 of 74.27.

Based on the analysis of variance, the results showed no significant difference $(\mathrm{P}<0.05)$ on body weight gain. This shows that the substitution of maize by using cassapro does not give a significant effect on the increase of chicken body weight. However, the average weight gain tendency in P2 (60.79) was higher when compared with $\mathrm{P} 0, \mathrm{P} 1, \mathrm{P} 3$ and $\mathrm{P} 4$. In this case it shows that nutrient content in maize and cassapro can be digested and utilized by livestock well, for basic living and also production.

This is in accordance with the statement of Tillesus et al., [2] which states that the productivity of cattle is very influenced by the amount of feed and nutrients that can be utilized by livestock. The quality of nutrients seen from the energy aspect contained in the consumed feed, not all of them are used by livestock, some are exploited, others are wasted through feces, urine, methane gas and heat. It is also supported by Sturkie's [3] statement which states that the metabolized energy demand is obtained by reducing the energy of ration with the excreta energy (feces and urine). Of the amount of energy it is not 
entirely can be used directly but there is still missing in the form of heat (heat increment) during the metabolism, so that live is a net energy.

From the results of the above study obtained that consumption at P0 is higher than the consumption of P2. While in body weight gain it was found that body weight gain at P2 was higher than P0. This tendency is probably due to the amino acid content contained in the cassapro more fully. The relationship between consumption and weight gain above is inconsistent with Anggorodi's [4] statement which states that low feed intake will cause a shortage of nutrients needed by livestock and consequently will inhibit fat and meat accumulation. If the need for basic life is met, the excess nutrients consumed will be deposited as fat and meat tissue.

From Table 4 above it can be seen that the average growth of chicken body weight of all treatments that is equal to 9.8 grams / head / day. The figure is the same as the UN standard on chicken maintenance according to Murtidjo [5] that is equal to $9.8 \mathrm{gram} / \mathrm{head} / \mathrm{day}$.

\subsection{Conversion Rations (Feed Converse Ratio)}

Ration conversion is a measure that can be used to assess the efficiency of ration use and quality of the ration. Conversion of ration is the ratio between the amount of ration consumed by the increase of body weight in a certain period. Rasyaf [6] states that the feed conversion ratio (Feed Converse Ratio) is the ratio of the number of feed consumption per week to the weight gain achieved that week. FCR can be searched by comparing the amount of rations consumed by chicken in a given period of time with live weight.

Table 5. Ration conversion during study (g/head/week)

\begin{tabular}{|c|c|c|c|c|c|c|c|}
\hline \multirow[b]{2}{*}{ Treatments } & \multicolumn{3}{|c|}{ Replication } & \multirow[b]{2}{*}{4} & \multirow[b]{2}{*}{ Total } & \multirow[b]{2}{*}{ Means } & \multirow[b]{2}{*}{$\begin{array}{l}\text { Standart } \\
\text { Deviasi }\end{array}$} \\
\hline & 1 & 2 & 3 & & & & \\
\hline P0 & 5,41 & 6,28 & 5,91 & 5,71 & 23,30 & 5,82 & 0,36 \\
\hline P1 & 5,14 & 5,60 & 5,84 & 5,49 & 22,07 & 5,52 & 0,29 \\
\hline $\mathrm{P} 2$ & 5,52 & 5,40 & 5,48 & 5,12 & 21,53 & 5,38 & 0,18 \\
\hline P3 & 5,73 & 5,45 & 6,34 & 5,64 & 23,16 & 5,79 & 0,39 \\
\hline $\mathrm{P} 4$ & 5,66 & 6,36 & 5,57 & 5,50 & 23,08 & 5,77 & 0,40 \\
\hline
\end{tabular}

Table 6. Annova Conversion of rations during the study ( $\mathrm{g} / \mathrm{head} /$ week)

\begin{tabular}{lllllll}
\hline & & & \multicolumn{3}{c}{ FTabel } \\
\cline { 5 - 7 } SK & $\mathrm{dB}$ & $\mathrm{JK}$ & $\mathrm{KT}$ & Fhit & 0,05 & 0,01 \\
\hline Perlakuan & 4 & 120,5747 & 30,14366 & 0,939 & 3,24 & 5,29 \\
Galat & 15 & 481,7284 & 32,11523 & & & \\
Total & 19 & 4809,715 & & & & \\
\hline
\end{tabular}

From table 6, it can be seen that the conversion of chicken ration during the study was not significantly different between treatments (P0, P1, P2, P3, P4). The highest ration conversion was in P0 of 5.82 , while the lowest ration conversion was in $\mathrm{P} 2$ of 5.38. The lower the value the conversion of rations is the more effective use of such rations as animal feed.

Based on the analysis of variance showed results that were not significantly different $(\mathrm{P}<0.05)$ to the conversion of rations. This indicates that corn and cassapro flour have no significant effect on conversion of chicken ration. It can be seen in the table that there is no significant difference from P0, P1, $\mathrm{P} 2, \mathrm{P} 3$, and P4. This is due to the nutritional content contained cassapro tend to be the same as the nutrients contained in corn. This is in accordance with the statement Kompiang [6] which states that through the fermentation process cassapro nutritional value of cassava can increase. Feed conversion is an indicator that can explain the efficient use of feed, where the lower the number means the better the feed conversion. 
From the results of the study it was found that P0 was the highest consumption while P1 was in second, while in P2 body weight increased higher than P0. Conversion of rations is the result of consumption by weight gain. Ration consumption and weight gain determine feed conversion. This is in accordance with the statement Martawidjaja [7], which states that the feed of good quality can produce high body weight gain. The use of feed will be more efficient when the amount of feed consumed is minimal but produces a high body weight gain.

\section{Conclusions and Recommendations}

From this research, it can be concluded that the use of cassapro (cassava protein) can replace corn up to $40 \%$ in chicken ration because nutrition value between corn with cassapro is almost the same.

It is advisable to farmers to use cassapro to replace corn in chicken rations if available in the amount of production and sustainability.

\section{References :}

Aisyah, T. dan Rachmat E. 1989. Pengaruh pemberian ransum starter terhadapPertambahan bobot badan anak ayam buras (Influence of starter ration feeding to increase of body weight of domestic chickens). Prosiding Seminar NasionalTentang Unggas Lokal. Semarang

Anggorodi, R. 1985. Ilmu Makanan Ternak Unggas (Science of Poultry Feed). (UI Press. Jakarta Anggorodi, R., 1995. Ilmu Makanan Ternak Umum (General Food Science). Gramedia. Jakarta

BPS. (2004). Kota Yogyakarta Dalam Angka 2004 (City of Yogyakarta In Figures 2004). Yogyakarta: Badan Pusat Statistik.

Badan Pusat Statistik Provinsi Sumatera Utara. 2012

Boonop, K., W. Metha, N. Ngarmnit and W. Sadudee. 2009. Enriching nutritive value of cassava root by yeast fermentation. Sci. Afri. J. 66(5): $629-633$.

Candrawati, D.P.M.A. 1999. Pendugaan Kebutuhan Energi dan Protein Ayam Kampung Umur 0-8 minggu (tesis) Estimating the Need for Chicken Energy and Protein Kampung Age 0-8 weeks (thesis). Bogor: Institut Pertanian Bogor.

Crawford, R.D. 1990. Poultry Biology: Origin and History of Poultry Species. In: R. D. Crawford (Edit.). Poultry Breeding and Genetics. Elsevier Science PublishingCompany Amsterdam and New York, pp:142. 